\title{
Subcutaneous Nogo Receptor Removes Brain Amyloid- $\beta$ and Improves Spatial Memory in Alzheimer's Transgenic Mice
}

\author{
James H. Park, ${ }^{1}$ Gabriel A. Widi, ${ }^{1}$ David A. Gimbel, ${ }^{1}$ Noam Y. Harel, ${ }^{1}$ Daniel H. S. Lee,${ }^{2}$ and Stephen M. Strittmatter ${ }^{1}$ \\ ${ }^{1}$ Program in Cellular Neuroscience, Neurodegeneration, and Repair, Yale University School of Medicine, New Haven, Connecticut 06510, and ${ }^{2}$ Biogen Idec, \\ Cambridge, Massachusetts 02140
}

\begin{abstract}
The production and aggregation of cerebral amyloid- $\beta(\mathrm{A} \beta)$ peptide are thought to play a causal role in Alzheimer's disease (AD). Previously, we found that the Nogo-66 receptor (NgR) interacts physically with both $\mathrm{A} \beta$ and the amyloid precursor protein (APP). The inverse correlation of $\mathrm{A} \beta$ levels with $\mathrm{NgR}$ levels within the brain may reflect regulation of $\mathrm{A} \beta$ production and/or $\mathrm{A} \beta$ clearance. Here, we assess the potential therapeutic benefit of peripheral NgR-mediated A $\beta$ clearance in APPswe/PSEN-1 $\triangle \mathrm{E} 9$ transgenic mice. Through site-directed mutagenesis, we demonstrate that the central 15-28 aa of $A \beta$ associate with specific surface-accessible patches on the leucine-rich repeat concave side of the solenoid structure of $\mathrm{NgR}$. In transgenic mice, subcutaneous $\mathrm{NgR}(310)$ ecto-Fc treatment reduces brain $\mathrm{A} \beta$ plaque load while increasing the relative levels of serum $\mathrm{A} \beta$. These changes in $\mathrm{A} \beta$ are correlated with improved spatial memory in the radial arm water maze. The benefits of peripheral $\mathrm{NgR}$ administration are evident when therapy is initiated after disease onset. Thus, the peripheral association of $\mathrm{NgR}(310)$ ecto- $\mathrm{Fc}$ with central $\mathrm{A} \beta$ residues provides an effective therapeutic approach for $\mathrm{AD}$.
\end{abstract}

Key words: Alzheimer's disease; $\beta$-amyloid; Nogo-66 receptor; axon; therapy; radial arm water maze; degeneration; amyloid precursor protein

\section{Introduction}

Neurodegeneration in Alzheimer's disease (AD) is accompanied by amyloid plaques and neurofibrillary tangles (Glenner et al., 1984; Hardy and Selkoe, 2002). The amyloid plaques are composed primarily of a $40-43$ aa amyloid- $\beta(\mathrm{A} \beta)$ peptide that is derived from proteolytic cleavage of amyloid precursor protein (APP) (Li et al., 1995; Sinha et al., 1999; Vassar et al., 1999). Potential therapies include decreasing $\beta$ production (Lanz et al., 2003 ) with secretase inhibitors, increasing $\beta$ degradation (Frautschy et al., 1992; Qiu et al., 1998; Bertram et al., 2000; Iwata et al., 2001; Yasojima et al., 2001), and promoting A $\beta$-specific immunity (Morgan et al., 2000; Lee, 2001; Younkin, 2001). However, problems with toxicity and clearing the blood-brain barrier (BBB) have hampered efforts to treat $\mathrm{AD}$ (Birmingham and Frantz, 2002; Orgogozo et al., 2003).

The Nogo-66 receptor (NgR) participates in limiting injuryinduced axonal growth and experience-dependent plasticity in the adult brain (Fournier et al., 2001; McGee and Strittmatter, 2003; McGee et al., 2005). In this role, it serves as a receptor for three myelin inhibitor proteins, Nogo, MAG, and OMgp, signal-

\footnotetext{
Received Aug. 10, 2006; accepted Nov. 12, 2006.

This work was supported by grants from the National Institutes of Health (NIH) to S.M.S. and by an institutional NIH Medical Scientist Training grant to J.H.P. S.M.S. is a member of the Kavli Institute of Neuroscience at Yale University. We thank Dave Morgan for counsel regarding radial arm water maze testing.

Correspondence should be addressed to Stephen M. Strittmatter, Department of Neurology, Yale University School of Medicine, P.0. Box 208018, New Haven, CT 06510. E-mail: stephen.strittmatter@yale.edu. DOI:10.1523/JNEUROSCI.4504-06.2006

Copyright $\odot 2006$ Society for Neuroscience $\quad$ 0270-6474/06/2613279-08\$15.00/0
}

ing to activate Rho GTPase in axons (Fournier et al., 2001, 2003; Liu et al., 2002; Wang et al., 2002; McGee and Strittmatter, 2003). Recently, we found that brain NgR interacts with APP through its $\mathrm{A} \beta$ domain (Park et al., 2006). Moreover, increased levels of brain $\mathrm{NgR}$ result in reduced $\mathrm{A} \beta$ load, whereas loss of endogenous $\mathrm{NgR}$ elevates $\mathrm{A} \beta$. Parallel changes in $\mathrm{A} \beta$ and secreted $\mathrm{APP} \alpha$ plus APP $\beta$ suggest that at least a portion of the in vivo effects of brain $\mathrm{NgR}$ on $\mathrm{A} \beta$ levels is mediated by blockade of $\alpha / \beta$-secretase activity. However, the high affinity of $\mathrm{NgR}$ for $\mathrm{A} \beta$ and the presence of $\mathrm{NgR}$ in plaques imply that $\mathrm{NgR}$ might also regulate the clearance of $\mathrm{A} \beta$ (Park et al., 2006).

Immunological methods have been successful in decreasing $\mathrm{A} \beta$ plaque burden, as reviewed by Schenk (2002). Both active and passive immunizations have promoted efflux, inhibited influx, or activated microglia-induced antibody $(\mathrm{Ab})$ degradation (Schenk et al., 1999; Morgan et al., 2000; Weiner and Selkoe, 2002). Active immunization with $A \beta(1-42)$ plus adjuvant in transgenic mutant APP reduced A $\beta$ plaque pathology (Schenk et al., 1999). Bard et al. (2000) demonstrated that humoral immunity is sufficient to reduce plaque burden by triggering $\mathrm{Ab}$ trafficking across the BBB. In contrast, DeMattos et al. (2001) demonstrated that an $\mathrm{A} \beta \mathrm{Ab}$ reduces Alzheimer pathology without Ab passage across the $\mathrm{BBB}$, implicating a peripheral sink mechanism for anti- $\mathrm{A} \beta$ reductions in Alzheimer's pathology. Different $\mathrm{A} \beta$ Abs recognizing various epitopes have significantly different actions in vivo. The $\mathrm{N}$-terminal $\mathrm{A} \beta$ residues serve as robust antigens for a humoral immune response, and passive administration of some (but not all) $\mathrm{N}$-terminal-directed Abs effectively remove $\mathrm{A} \beta$ from 
the brain (Bard et al., 2000). Passive transfer of one midportion $\mathrm{A} \beta \mathrm{Ab}$ is highly effective in removing $\mathrm{A} \beta$ from the mouse brain (DeMattos et al., 2001). As antigens, the C-terminal residues of $\mathrm{A} \beta$ appear to yield $\mathrm{Abs}$ that are less effective in reducing $\mathrm{A} \beta$ burden (Levites et al., 2006).

In a range of studies, reducing $A \beta$ burden in the brain by immunological means has been associated with improved spatial memory performance in Alzheimer model transgenic mice. However, in several reports, behavioral improvements occurred acutely, before any change in plaque density, suggesting the Ab association with particular soluble $\mathrm{A} \beta$ species is responsible for improved function. Two non-Ig proteins, RAGE and gelsolin, have been shown to bind $\mathrm{A} \beta$ and, when administered peripherally, to decrease brain $A \beta$ load (Deane et al., 2003; Matsuoka et al., 2003; Arancio et al., 2004). This supports the peripheral sink hypothesis for passive immunization against $A \beta$. Whether $A \beta$ reduction by peripheral non- $\mathrm{Ab} \mathrm{A} \beta$-binding proteins is associated with improved cognitive and memory function has not been tested.

Because previous studies suggest that $\mathrm{A} \beta$ burden can be reduced by peripheral administration of $A \beta$-binding agents, we hypothesized that the high affinity of $\mathrm{NgR}$ for $\mathrm{A} \beta$ should also reduce CNS A $\beta$ levels through a peripheral sink mechanism. In this report, we define the amino acid residue requirements for the $\mathrm{A} \beta-\mathrm{NgR}$ interaction. We demonstrate that subcutaneous $\mathrm{NgR}(310)$ ecto-Fc reduces plaque burden after disease onset in APPswe/PSEN-1 $\Delta \mathrm{E} 9$ transgenic mice. Most critically, $\mathrm{NgR}(310)$ ecto-Fc treatment improves short-term memory of Alzheimer transgenic mice in the radial arm water maze (RAWM) task.

\section{Materials and Methods}

$\mathrm{NgR}$ mutagenesis and ligand-binding assays. AP-A $\beta$ and AP-Nogo proteins were produced as described previously (Fournier et al., 2001; Park et al., 2006). To generate AP-A $\beta$ mutant constructs, $A \beta$ fragments were amplified, ligated into the pAP5tag vector (GenHunter, Nashville, TN), and sequenced. Recombinant proteins were confirmed by immunoblotting. The binding of AP fusion proteins to transfected COS-7 cells has been described previously (Fournier et al., 2001). COS-7 cells were transfected with p75-NTR and RAGE, membrane proteins reported to bind $\mathrm{A} \beta$ (Deane et al., 2003) (Yaar et al., 1997). Synthetic $A \beta(1-28)$ was used to assess AP-A $\beta(1-28)$ and AP-Nogo-66(1-33) displacement from immobilized $\mathrm{NgR}(310)$ ecto-Fc in an ELISA format.

NgR mutagenesis has been described previously (Fournier et al., 2003; $\mathrm{Hu}$ et al., 2005). Bound AP was stained and measured using NIH Image software. Mutants of human NgR were detected immunofluorescently on the surface of transfected COS-7 cells. Whole COS-7 cell lysates expressing NgR mutants were subjected to SDS-PAGE and blotted with anti-NgR Abs.

Treatment of transgenic mice with $\mathrm{NgR}$. To administer rat NgR(310)ecto-Fc protein, APPswe/PSEN-1 $\Delta$ E9 mice (Park et al., 2006) from The Jackson Laboratory (Bar Harbor, ME) were anesthetized with isoflurane and oxygen, and an Alzet (Cupertino, CA) osmotic pump 2004 was subcutaneously inserted over the scapula and allowed to rest between fascia. The $200 \mu \mathrm{l}$ pump delivered $0.25 \mu \mathrm{l} / \mathrm{h}$ for $28 \mathrm{~d}$ of a 1.2 $\mu \mathrm{g} / \mu \mathrm{l}$ solution of rat $\mathrm{NgR}(310)$ Ecto-Fc or rat IgG in PBS. Pumps were replaced after $28 \mathrm{~d}$ for a total treatment duration of 12 weeks. The anti-A $\beta$ (6E10) Ab was from Chemicon (Temecula, CA). DAB staining reagents were from Vector Laboratories (Burlingame, CA).

Biochemical and histological analyses. Brains from subcutaneously treated APPswe/PSEN-1 $\Delta$ E9 transgenic mice were homogenized in PBS plus a protease inhibitor mixture (Roche Products, Welwyn Garden City, UK), followed by centrifugation at $100,000 \times g$ for $20 \mathrm{~min}$. Secreted $\operatorname{APP} \alpha(\operatorname{sAPP} \alpha)$ was measured by immunoblot analysis with $6 \mathrm{E} 10$ anti$\mathrm{A} \beta$-(1-17) Ab (Park et al., 2006) (Chemicon). Alternatively, the brain extract was subjected to Protein A/G Plus Sepharose (Pierce, Rockford, IL) immunoprecipitation and analyzed by anti-NgR polyclonal $\mathrm{Ab}$ (AF1440; R \& D Systems, Minneapolis, MN). A $\beta$ ELISAs were performed according to the manufacturer's protocol (Biosource, Camarillo, CA), as described for formic acid extracts of the brain (Park et al., 2006). A $\beta$ plaques in parasagittal sections were fixed by paraformaldehyde and labeled with anti-A $\beta$-(1-17) $6 \mathrm{E} 10 \mathrm{Ab}$ after $0.1 \mathrm{~m}$ formic acid treatment (Park et al., 2006). Plaque area was quantitated as a percentage of total cerebral cortical area for two sections from each animal using NIH Image software. Neuritic dystrophy and reactive astrocytosis were visualized by staining with monoclonal anti-synaptophysin GA-5 (Sigma, St. Louis, MO) and monoclonal anti-GFAP SY38 (Chemicon) in parasagittal paraffin-embedded sections. The area of the cerebral cortex and hippocampus occupied by clusters of dystrophic neurites and reactive astro- a

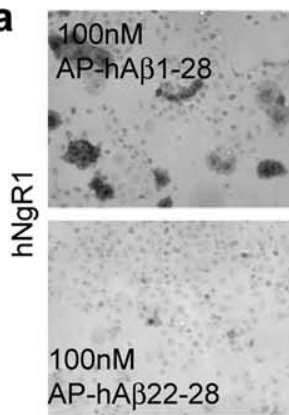

b

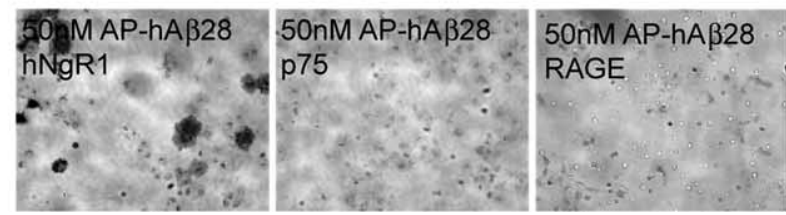

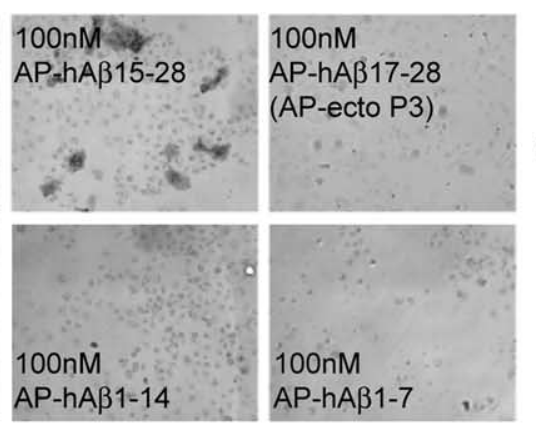

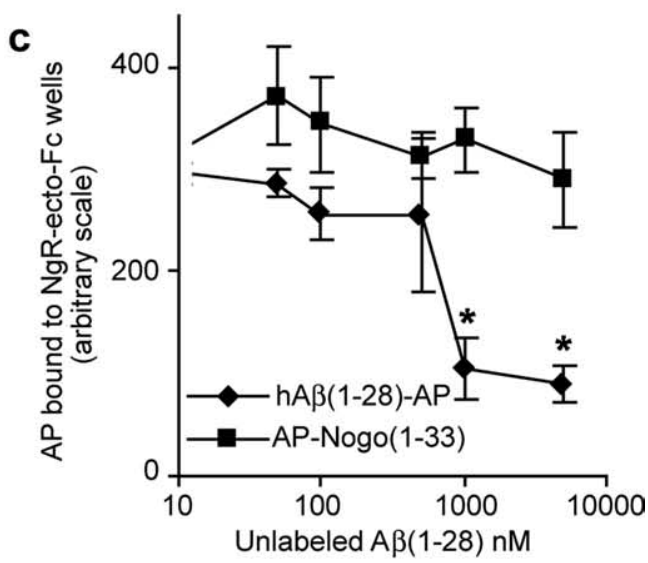

Figure 1. Residues $15-28$ in $A \beta(1-28)$ are essential for binding to NgR. $\boldsymbol{a}$, Deletion mapping of the AP-A $\beta(1-28)$ region required for binding to COS-7 cells expressing wild-type NgR. The 8 -28 construct demonstrates strong binding, 15-28 shows weaker binding, but the 1-21, 1-14, 1-7, 22-28, and 17-28 fragments do not support AP binding to NgR-expressing cells. $\boldsymbol{b}$, AP-A $\beta(1-28)$ does not bind to COS-7 cells expressing p75-NTR or RAGE under conditions that allow binding to cells expressing NgR. c, Displacement of AP-A $\beta(1-28)$ but not AP-Nogo-66(1-33), from NgR by $A \beta(1-28)$. A concentration of $250 \mathrm{~nm}$ soluble AP-A $\beta(1-28)$ or AP-Nogo-66(1-33) was allowed to bind to wells coated with purified NgR(310)ecto-Fc in the presence of the indicated concentrations of free $A \beta(1-28)$. In this cell-free assay, avidity for $\mathrm{NgR}$ is reduced compared with the cell-based binding system, and the measured $K_{\mathrm{i}}$ for $A \beta(1-28)$ is $700 \mathrm{~nm}$. Data are means \pm SEM from four experiments. ${ }^{*} p<0.05$, significant inhibition by $A \beta(1-28)$ (ANOVA). 
cytes were measured as a percentage of total area by the same method as $\mathrm{A} \beta$ plaque load (Park et al., 2006). DAB staining reagents were from Vector Laboratories.

RAWM testing. A modified RAWM testing protocol was based on a communication with D. Morgan (Wilcock et al., 2006). The maze consisted of a circular pool $1 \mathrm{~m}$ in diameter with six swim alleys $19 \mathrm{~cm}$ wide that radiated out from a $40 \mathrm{~cm}$ open central area, and a submerged escape platform was located at the end of one arm. Spatial cues were presented on the walls and at the end of each arm. The behaviorist was blind to the treatment and genotype. To control for vision, motivation, and swimming, mice were tested in an open-water visual-platform paradigm for up to $1 \mathrm{~min}$, and latency times were recorded. Next, mice were placed in a random arm according to the following: Excel function = MOD $[$ \$CELL+RANDBETWEEN $(1,5), 6]$, where \$CELL is the location of the hidden platform. Each mouse was allowed to swim for up to $1 \mathrm{~min}$ to find the escape platform. After entering an incorrect arm (all four paws within that swim alley) or failing to select an arm after $20 \mathrm{~s}$, the mouse was pulled back to the start arm and charged an error. All mice spent $30 \mathrm{~s}$ on the platform after each trial before beginning the next trial. Thereafter, the mouse was tested four more times, constituting a learning block. Mice were allowed to rest for $30 \mathrm{~min}$ between learning blocks. In total, mice were tested over three learning blocks of five trials over the first day and then three blocks of five trials on the subsequent day. Through the group of 30 trials, the hidden platform position was kept constant for each mouse.

Statistical comparisons were made using ANOVA tests and SPSS 11 software (SPSS, Chicago, IL).

\section{Results}

Before assessing NgR as a therapeutic agent in Alzheimer model systems, we extended our characterization of the specificity of $A \beta$ interaction with $\mathrm{NgR}$. First, we sought to determine whether a linear subsegment of $A \beta(1-28)$ might interact with $\mathrm{NgR}$ in a cell-binding assay. We created deletion constructs containing various portions of the $\mathrm{A} \beta$ ectodomain fused to AP. The region of $\mathrm{A} \beta$ responsible for $\mathrm{NgR}$ interaction localizes to residues $15-28$, the central residues of $\mathrm{A} \beta(1-40)$ (Fig. $1 a)$.

We also compared the binding of $\mathrm{AP}-\mathrm{A} \beta(1-28)$ to $\mathrm{NgR}$ with other reported partners, p75 and RAGE (Yaar et al., 1997; Deane et al., 2003). Under conditions in which AP-A $\beta(1-28)$ binding to $\mathrm{NgR}$ is readily detectable, p75 and RAGE do not exhibit a significant interaction with $\mathrm{A} \beta$ fusion protein (Fig. $1 b$ ).

$\mathrm{NgR}$ was identified by virtue of its affinity for Nogo-66, so we considered whether $\mathrm{A} \beta$ and Nogo-66 compete for binding to $\mathrm{NgR}$. Competition was assessed in binding assays of AP-A $\beta(1-$ 28) or AP-Nogo66(1-33) to immobilized, purified NgR protein. Synthetic $A \beta(1-28)$ disrupts the ability of $\mathrm{NgR}$ to interact with the $A \beta$ ligand but not the Nogo-66 ligand (Fig. 1c). Thus, the two ligand-binding sites of $\mathrm{NgR}$ are distinguished by this assay.

To probe the NgR domains that interact with $\mathrm{A} \beta$ and Nogo66 , a strategy based on the crystal structure of NgR was used. A number of human $\mathrm{NgR}$ surface-accessible residues were mutated to Ala either individually or as groups of adjacent residues (Table 1 ), and resultant ligand-binding characteristics were assessed. The expression of each mutant NgR protein was verified by immunohistochemical detection at the surface of cells transfected with expression vector (Fig. $2 a$ ). For each of the mutants with altered binding characteristics, expression of immunoreactive NgR protein with electrophoretic mobility similar to wild type was also confirmed by immunoblot analysis (Fig. 2c). The mobility of each mutant was indistinguishable from wild-type $\mathrm{NgR}$, except for the mutations in $\mathrm{N}$-linked glycosylation sites (N82 and N179).

The binding of both AP-A $\beta(1-28)$ and AP-Nogo-66 ligands to cells expressing this collection of $\mathrm{NgR}$ mutant proteins was
Table 1. Summary of human $\mathrm{NgR}$ mutants: list of residues mutated to alanine

\begin{tabular}{|c|c|c|}
\hline No binding & $\begin{array}{l}\text { Binding to AP-Ng-66 } \\
\text { and AP-A } \beta 28\end{array}$ & $\begin{array}{l}\text { Differential } \\
\text { binding }\end{array}$ \\
\hline 163 & 61 & 210 \\
\hline 82,179 & 92 & $256,259,284$ \\
\hline 133,136 & 108 & \\
\hline 158,160 & 122 & \\
\hline 182,186 & 127 & \\
\hline 211,213 & 131 & \\
\hline 232,234 & 138 & \\
\hline $111,113,114$ & 139 & \\
\hline $182,186,210$ & 151 & \\
\hline $111,113,114,138$ & 176 & \\
\hline $182,186,158,160$ & 179 & \\
\hline $189,191,211,213$ & 227 & \\
\hline $211,213,237,256,259,284$ & 237 & \\
\hline $171,172,175,176,196,199,220,223,224,250$ & 250 & \\
\hline $67,68,71$ & 259 & \\
\hline $67,68,71,89,90,92$ & 108,131 & \\
\hline $87,89,133,136$ & 114,117 & \\
\hline \multirow[t]{34}{*}{ Negative control } & 127,151 & \\
\hline & 127,176 & \\
\hline & 143,144 & \\
\hline & 189,191 & \\
\hline & 196, 199 & \\
\hline & 202,205 & \\
\hline & 256,259 & \\
\hline & 267,269 & \\
\hline & 277,279 & \\
\hline & $114,117,139$ & \\
\hline & $189,191,237$ & \\
\hline & $189,191,284$ & \\
\hline & $202,205,227$ & \\
\hline & $202,205,250$ & \\
\hline & $220,223,224$ & \\
\hline & $237,256,259$ & \\
\hline & $296,297,300$ & \\
\hline & $171,172,175,176$ & \\
\hline & $292,296,297,300$ & \\
\hline & $196,199,220,223,224$ & \\
\hline & $\begin{array}{l}171,172,175,176,196 \\
199\end{array}$ & \\
\hline & $\begin{array}{l}196,199,220,223,224 \\
\quad 250\end{array}$ & \\
\hline & $108,131,61$ & \\
\hline & 36,38 & \\
\hline & $36,38,61$ & \\
\hline & $61,131,36,38$ & \\
\hline & 63,65 & \\
\hline & 78,81 & \\
\hline & 87,89 & \\
\hline & $89,90,114,117$ & \\
\hline & 95,97 & \\
\hline & $\begin{array}{l}95,97,117,119,120, \\
188.189\end{array}$ & \\
\hline & $95,97,122$ & \\
\hline & Wild type & \\
\hline
\end{tabular}

Ala-substituted human NgR mutants were tested for their binding to AP-A $\beta(1-28)$ and AP-Nogo-66. There are three categories, as follows: (1) NgR mutants that lose binding to both ligands, (2) mutants that maintain binding to all NgR ligands, and (3) differential-binding mutants that bind AP-Nogo-66 but not AP-A $\beta(1-28)$.

assessed at concentrations equal to the predetermined $K_{\mathrm{D}}$ of the ligands (Fig. $2 b, d$ ). A large group of amino acids are unnecessary for the binding of either ligand (Table 1; Fig. 2e, green); this includes all of the residues examined from the convex side of the $\mathrm{NgR}$ leucine-rich repeat (LRR) domain. Another subset of amino acids is essential for the binding of both $A \beta(1-28)$ and Nogo-66 
a
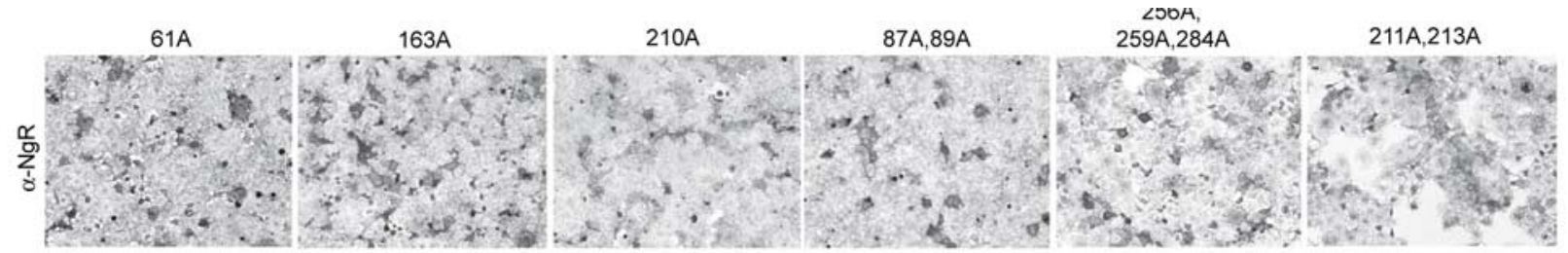

b

AP

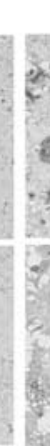

AP-Nogo66

\section{AP-AB28}

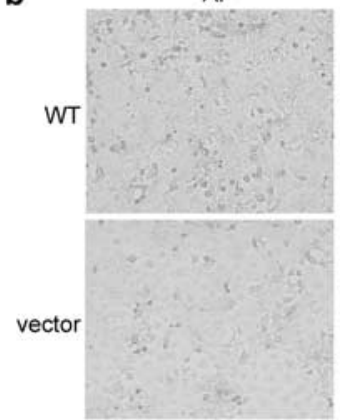

$61 \mathrm{~A}$

$163 \mathrm{~A}$

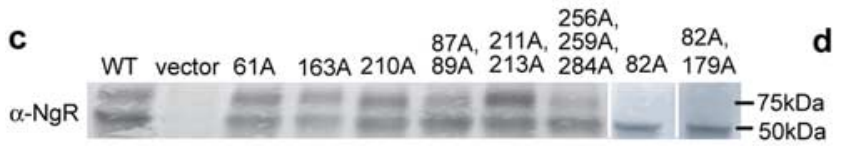

e
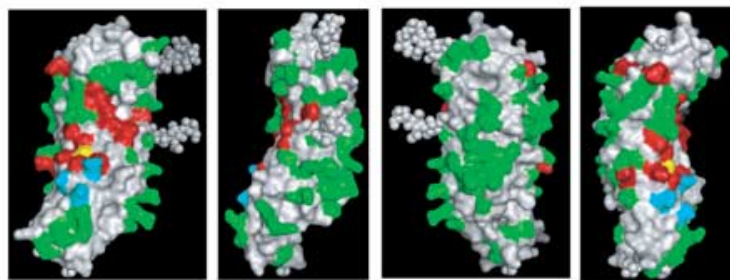

Residue Type

$\square$ Essential Residues

Non-Essential Residues

$\square$ Differential Single Residue

$\square$ Differential Triplet Residues

Figure 2. Specific residues in NgR support binding to AP-A $\beta(1-28)$. $\boldsymbol{a}$, Mutant NgR proteins at the surface of transfected COS-7 cells were detected by immunostaining with rabbit anti-NgR Ab recognized by anti-rabbit-AP. $\boldsymbol{b}$, Binding of AP or AP-fused NgR ligands to COS-7 cells expressing NgR mutants displaying differential binding. The ligand concentrations were as follows (in nM): 30 AP, 5 AP-Nogo-66, and 50 AP-A $\beta(1-28)$. c, Cell lysate of COS-7 cells expressing NgR and mutants were immunoblotted with anti-NgR Ab to ascertain molecular weight and expression levels. $\boldsymbol{d}$, Quantitation of AP binding of NgR ligands to $\mathrm{NgR}$ mutants expressed as a percentage of wild-type NgR. After incubation with AP-fused ligands, AP bound to COS-7 cells expressing NgR were stained and measured. Data are mean \pm SEM from four independent samples. ${ }^{*} p<0.01$, significant difference for binding of the two ligands. $\boldsymbol{e}$, The molecular surface of NgR is illustrated with residues essential for binding AP-Nogo-66 and AP-A $3(1-28)$ labeled red, residues not required for ligand binding labeled blue, and residues required for differential binding labeled yellow. Pictures were created using PyMol. The molecules are positioned with their $\mathrm{N}$ termini pointing up and their C termini pointing down. WT, Wild type.

(Table 1; Fig. 2e, red). Because these amino acids do not alter the localization or molecular size of $\mathrm{NgR}$ protein and are clustered in close proximity on the concave surface, we hypothesize that they form a core ligand-binding site. This is consistent with the observation that for other LRR proteins, such as the folliclestimulating hormone receptor, ligand binding predominantly occurs on the concave side (Fan and Hendrickson, 2005). Without structural studies, the possibility that these mutations prevent native $\mathrm{NgR}$ protein folding cannot be excluded. Most interesting are a third group of amino acids, for which Ala substitution results in NgR binding of Nogo-66 but not A $\beta(1-28)$ (Table 1; Fig. $2 e$, blue or yellow). Because AP-Nogo-66 binding is indistin- 


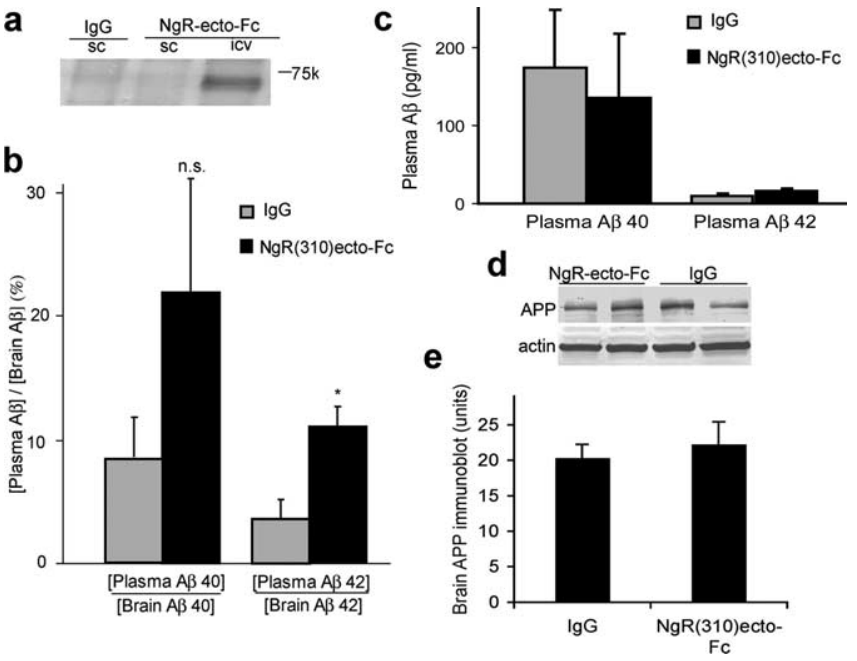

Figure 3. $\mathrm{NgR}(310)$ ecto-Fc treatment acts peripherally to alter the plasma/brain $A \beta$ ratio. $\boldsymbol{a}, \mathrm{An}$ anti-NgR immunoblot of protein $\mathrm{A} / \mathrm{G}$ binding proteins in brain lysate of APPswe/PSEN$1 \Delta \mathrm{E} 9$ transgenic mice treated subcutaneously (sc) with rat $\mathrm{lgG}$, subcutaneously with $\mathrm{NgR}(310)$ ecto-Fc, or intracerebroventricularly (icv) with $\mathrm{NgR}(310)$ ecto-Fc. The dose of each protein was $0.27 \mathrm{mg} / \mathrm{kg} / \mathrm{d}$. $\boldsymbol{b}$, The ratio of plasma versus brain $A \beta$ level in APPswe $/ P S E N-1 \Delta E 9$ transgenic mice at 10 months of age is plotted as a percentage. In each sample, levels of $A \beta(1-40)$ and $A \beta(1-42)$ were assessed by ELISA. After 3 months of subcutaneous treatment, there is a significant increase in the plasma/brain $A \beta\left(1-42\right.$ ) ratio. ${ }^{*} p<0.05$ (ANOVA). n.s., Not significant. $c$, The absolute level of plasma $A \beta$ level in APPswe/PSEN- $1 \Delta$ E9 transgenic mice at 10 months of age is plotted. The differences are not significant. $\boldsymbol{d}$, An anti-APP (6E10) immunoblot of brain lysate of APPswe/PSEN- $1 \Delta \mathrm{E} 9$ transgenic mice treated subcutaneously with rat IgG or subcutaneously with $\mathrm{NgR}(310)$ ecto-Fc from 7 to 10 months of age. The dose of each protein was $0.27 \mathrm{mg} / \mathrm{kg} / \mathrm{d}$, by continuous infusion. $e$, The level of anti-APP immunoreactivity in brain lysates from an experiment as in c is plotted. Data are mean \pm SEM from $n=4-5$ mice.

guishable from wild-type $\mathrm{NgR}$, aberrant protein folding is unlikely to be the basis for reduced $\mathrm{A} \beta$ binding. Instead, $\mathrm{NgR}$ amino acids $210,256,259$, and 284 are likely to contribute selectively to $\mathrm{A} \beta$ but not Nogo-66 interaction.

Although endogenous NgR plays a role in limiting $\mathrm{A} \beta$ production and deposition, the affinity of $\mathrm{NgR}$ for the central domain of $A \beta$ suggests that it might promote peripheral clearance if delivered outside of the CNS. To examine whether rat $\mathrm{NgR}(310)$ ecto-Fc administered subcutaneously enters the brain of mouse, we assayed the presence of $\mathrm{NgR}(310)$ ecto-Fc in brain lysates. The $\mathrm{NgR}(310)$ ecto-Fc fusion protein or control rat Ig was concentrated by protein A/G affinity chromatography. Although intracerebroventricular administration leads to easily detected $\mathrm{NgR}(310)$ ecto-Fc levels in brain tissue, no $\mathrm{NgR}(310)$ ecto-Fc is detected centrally after subcutaneous treatment (Fig. $3 a$ ). This is consistent with the hypothesis that $\mathrm{NgR}(310)$ ecto-Fc cannot pass the BBB to an appreciable degree in APPswe/PSEN-1 $\Delta \mathrm{E} 9$ mice.

To the extent that $\mathrm{NgR}(310)$ ecto-Fc functions as a peripheral sink for $\mathrm{A} \beta$, the ratio of plasma to brain $\mathrm{A} \beta$ should be elevated, as shown for anti-A $\beta$ treatment. Levels of $A \beta 40$ and $A \beta 42$ were assessed by ELISA in brain and plasma samples from peripherally treated mice (Fig. $3 b$ ). Subcutaneous treatment with $\mathrm{NgR}(310)$ ecto-Fc increases plasma to brain ratios for $\mathrm{A} \beta$ by more than twofold. The increase in this ratio is primarily attributable to a decrease in brain levels with $\mathrm{NgR}(310)$ ecto-Fc treatment (see brain analysis below) and not to a change in plasma levels (Fig. $3 c$ ). Previously, we noted that central, intracerebroventricularly administered $\operatorname{NgR}(310)$ ecto-Fc reduces levels of $\operatorname{sAPP} \alpha$ and sAPP $\beta$ protein in the brain (Park et al., 2006). If subcutaneous $\mathrm{NgR}(310)$ ecto-Fc acts to alter $\mathrm{A} \beta$ clearance in the periphery, and not to alter $\mathrm{A} \beta$ production centrally, then similar changes in APP should fail to occur with peripheral treatment. Indeed, brain APP levels are not altered by subcutaneous $\mathrm{NgR}(310)$ ecto-Fc (Fig. 3d,e).

The restriction of subcutaneous $\mathrm{NgR}(310)$ ecto-Fc to the periphery allows an assessment of its effect as a "sink" on central A $\beta$ burden. Treatment of APPswe/PS-1 $\Delta \mathrm{E} 9$ transgenic mice was initiated at 7 months of age when the mice have become symptomatic, as judged by $\mathrm{A} \beta$ deposition in brain and by reduced spatial memory function (see below). After 3 months of subcutaneous treatment with $0.27 \mathrm{mg} / \mathrm{kg} / \mathrm{d} \mathrm{NgR(310)ecto-Fc} \mathrm{versus} \mathrm{IgG,} \mathrm{the}$ brain was examined. The total $\mathrm{A} \beta(1-40)$ and $\mathrm{A} \beta(1-42)$ levels as well as $\mathrm{A} \beta$ plaque are decreased significantly by $\mathrm{NgR}(310)$ ecto-Fc, to a level $\sim 50 \%$ less than the control (Fig. $4 a, d, e$ ). In parallel, dystrophic neurites detected by antisynaptophysin staining are decreased by peripheral $\mathrm{NgR}(310)$ ecto-Fc treatment (Fig. $4 b, f$ ). Astrogliosis detected by anti-GFAP staining intensity was also reduced significantly by therapy with peripheral $\mathrm{NgR}(310)$ ecto-Fc (Fig. $4 c, g$ ). Thus, delayed subcutaneous administration of $\mathrm{NgR}(310)$ ecto-Fc suppresses histologic evidence of $\mathrm{A} \beta$-associated disease in transgenic mice.

The ability of subcutaneous $\mathrm{NgR}(310)$ ecto-Fc therapy to reduce $\mathrm{A} \beta$ plaque is encouraging, but cognitive performance is the relevant symptom in clinical AD. To assess APPswe/PSEN-1 $1 \mathrm{E} 9$ transgene-related impairments in spatial memory and learning over a $24 \mathrm{~h}$ period, we used a modified RAWM paradigm (Wilcock et al., 2006). If performance on this task reflects spatial learning and not alterations in motivation, motor coordination, stamina or vision, then the latency to reach a visible escape platform should not differ between groups. Such latencies are indistinguishable between littermate-matched wild-type and APPswe/ PS $-1 \Delta$ E9 mice ( $38 \pm 2 \mathrm{~s}$ vs $42 \pm 5 \mathrm{~s}$, respectively; mean \pm SEM; $n=8-10$ mice). Learning deficits in the $24 \mathrm{~h}$ spatial memory task are apparent in APPswe/PSEN-1 $\Delta \mathrm{E} 9$ versus wild-type littermate mice by 4 months of age (Fig. 5a). By 13 months of age, wild-type mice perform less well at this task than do young mice, whereas APPswe/PSEN-1 $\Delta$ E9 transgenic mice are completely unable to learn the task in our training paradigm illustrating disease progression (Fig. $5 b$ ). As a control, loss of $\mathrm{NgR}$ expression (in $n g r-/-$ mice) does not significantly alter RAWM performance (Fig. $5 c$ ).

The number of swim errors made by APPswe/PS- $1 \Delta \mathrm{E} 9$ mice after 20 training trials increases steadily at 8,9, and 10 months when mice receive control IgG therapy subcutaneously for 1,2 , or 3 months. In contrast, mice treated with subcutaneous $\mathrm{NgR}(310)$ ecto-Fc exhibit a halt in disease progression and show a trend toward improved performance after 3 months, by 10 months of age (Fig. $5 d$ ). RAWM errors are significantly reduced after 2 and 3 months of subcutaneous $\mathrm{NgR}(310)$ ecto-Fc treatment compared with rat IgG-treated mice (ANOVA, $p<0.05$ and 0.02 , respectively). These differences are related to improved memory function rather than altered vision, motivation, or motor capacity because no significant difference was observed in visible platform escape latencies between these groups (supplemental Fig.1, available at www.jneurosci.org as supplemental material). The improved performance of the $\mathrm{NgR}(310)$ ecto-Fctreated mice is not present during initial swim trials but develops during the $24 \mathrm{~h}$ training period (supplemental Fig. 2, available at www.jneurosci.org as supplemental material). There is a positive correlation between the average RAWM errors and the density of $\mathrm{A} \beta$-immunoreactive deposits across the two groups (Fig. $5 e$ ).

\section{Discussion}

In the present study, we have defined the molecular requirements for $\mathrm{A} \beta$ interaction with $\mathrm{NgR}$ and exploited the affinity of these 
polypeptides to demonstrate a subcutaneous method for alleviating memory impairments in AD model mice. The 15-28 central residues of $A \beta$ bind to a pocket on the concave surface of $\mathrm{NgR}$ that can be distinguished from the surface required for Nogo-66 binding. When NgR is administered subcutaneously, the protein does not enter the brain but can functionally shift $\mathrm{A} \beta$ from the brain to plasma. The net result of this shift is a lessening of ADrelated pathology. Most critically, peripheral NgR(310)ecto-Fc improves memory performance even when treatment is initiated after symptoms develop. Thus, $\mathrm{NgR}$ therapy provides an alternative to immune-based $\mathrm{A} \beta$ therapies for $\mathrm{AD}$.

In previous work, we had administered $\mathrm{NgR}(310)$ ecto-Fc intracerebroventricularly rather than subcutaneously to transgenic AD mice (Park et al., 2006). Similar reductions in $\mathrm{A} \beta$ were detected, but memory deficits were not assessed. Interestingly, the central administration of $\operatorname{NgR}(310)$ ecto-Fc reduced brain $\operatorname{sAPP} \alpha$ as well as $A \beta$. Furthermore, the elevated $A \beta$ and $\operatorname{sPP} \alpha$ in mice lacking NgR indicated that endogenous neuronal NgR serves to limit $A \beta$ production. Thus, the binding of excess NgR to both APP and $A \beta$ has the potential to reduce $A \beta$ production as well as to enhance $\mathrm{A} \beta$ clearance. The predominant action of subcutaneous NgR is the acceleration of $\mathrm{A} \beta$ clearance.

The reduction in both $A \beta$ and memory deficits with a nonimmunologic NgR protein provides additional evidence for the amyloid hypothesis of $\mathrm{AD}$ and also for the peripheral sink hypothesis of anti-A $\beta$ Ab function. Several previous studies demonstrate that peripheral administration of Abs directed against $\mathrm{A} \beta$ reduces $\mathrm{AD}$ pathology. The $\mathrm{A} \beta$ residues recognized by NgR match most closely to the $A \beta(13-28)$ epitope reacting with the $266 \mathrm{Ab}$. Like $\mathrm{NgR}(310)$ ecto-Fc, the $\mathrm{m} 266 \mathrm{Ab}$ reduces plaque burden (DeMattos et al., 2001; Dodart et al., 2002). As opposed to active or passive immunologic reagents, $\mathrm{NgR}$ is an endogenous protein and is not predicted to activate or to require cell-mediated mechanisms to reduce $A \beta$ levels and $\mathrm{A} \beta$-associated cognitive deficits. Two other non-Ig proteins, RAGE and gelsolin, have been shown to bind $\mathrm{A} \beta$ and to decrease brain A $\beta$ load (Deane et al., 2003; Matsuoka et al., 2003; Arancio et al., 2004) when administered peripherally. However, the effect of these proteins on memory function has not been examined, and shifts in $\mathrm{A} \beta$ are complicated by the fact that endogenous gelsolin is cytoplasmic and that RAGE alters BBB transport (Deane et al., 2003).

Several recent studies indicate that specific $A \beta$ isoforms, such as soluble oligomers including $\mathrm{A} \beta \beta^{\star} 56$, are better correlated with memory impairment than the total $\mathrm{A} \beta$ load in the brain (McLaurin et al., 2006). In our study, errors in RAWM performance and total brain $\mathrm{A} \beta$ deposition are directly correlated. This suggests that $\mathrm{NgR}(310)$ ecto-Fc does not distinguish between $\mathrm{A} \beta$ isoforms. The time course of improvement in memory performance after $\mathrm{NgR}(310)$ ecto-Fc is slow. After 1 month, the differ- b

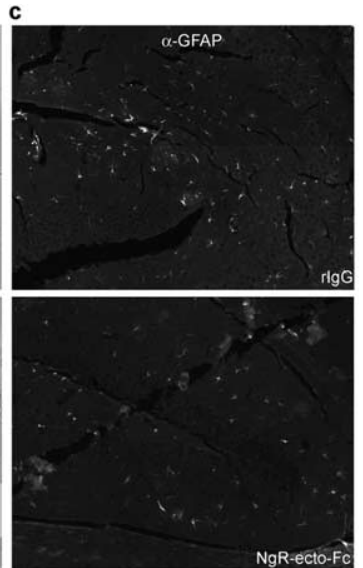

f
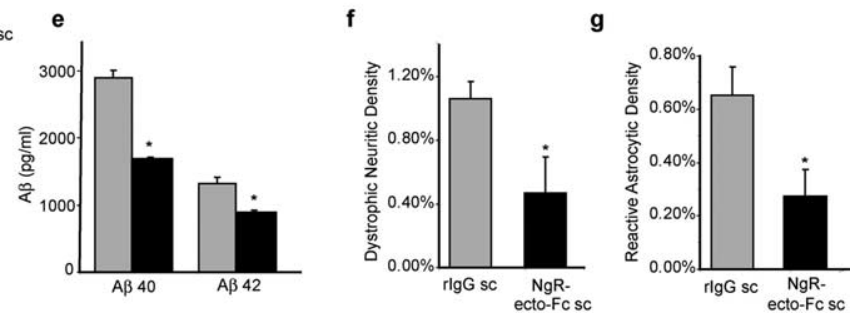

Figure 4. Reduction in $A \beta$ plaque load, neuritic dystrophy, and astrocytosis in NgR(310)ecto-Fc-treated APPswe/PSEN-1 $1 \Delta$ E9 age, brain tissue was analyzed by immunohistochemistry and ELISA. Data are means \pm SEM from nine mice in the rat

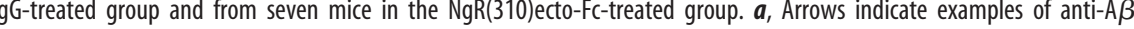
dystrophic neurites is reported for images as in $\boldsymbol{b}$. The decrease in neuritic dystrophy density is significant. $p<0.05$ (Student's $t$ test). $\boldsymbol{g}$, The percentage of area occupied by anti-GFAP immunoreactivity was measured from images as in $\boldsymbol{c}$. The decrease in anti-GFAP immunoreactivity is significant. $p<0.05$ (ANOVA).

ences are minimal, whereas they are clear at 2 months and dramatic at 3 months of treatment. This suggests that NgR is not binding acutely to a small pool of a function-blocking species of $\mathrm{A} \beta$ to promote rapid reversal of cognitive impairment but, rather, is leading to a shift in the steady-state levels of multiple $\mathrm{A} \beta$ forms in the brain through slow equilibration with species bound peripherally to the infused NgR protein. Future studies are required to directly assess $\mathrm{NgR}$ affinity for different $\mathrm{A} \beta$ forms and their regulation by subcutaneous $\mathrm{NgR}(310)$ ecto-Fc infusion.

In the current study, $\mathrm{NgR}$ affinity for $\mathrm{A} \beta$ has been defined and exploited for therapeutic benefit. CNS myelin also contains ligands for the NgR. The interaction of myelin with NgR limits experience-dependent plasticity in the cerebral cortex (McGee et al., 2005) and injury-induced regenerative axonal growth (GrandPre et al., 2002; Li and Strittmatter, 2003; Kim et al., 2004; Li et al., 2004, 2005). The influence of $A \beta$ with the myelin/NgR within the brain remains to be defined. Because human $\mathrm{A} \beta$ binding to human $\mathrm{NgR}$ exhibits a substantially higher affinity than mouse $\mathrm{A} \beta$ for mouse $\mathrm{NgR}$ (Park et al., 2006), and because $\mathrm{A} \beta$ levels are low without disease, the $\mathrm{A} \beta-\mathrm{NgR}$ interaction may function only in the pathological $\mathrm{AD}$ state. Alternatively, $\mathrm{A} \beta$ regulation of NgR-dependent axonal plasticity may contribute to impaired cognitive function in $\mathrm{AD}$.

The LRR protein family is involved in multiple protein-protein interactions. LRR domains contribute to the ectodomain 
a

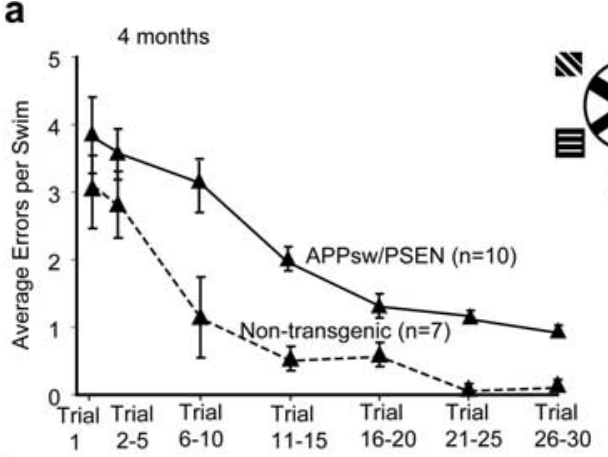

b

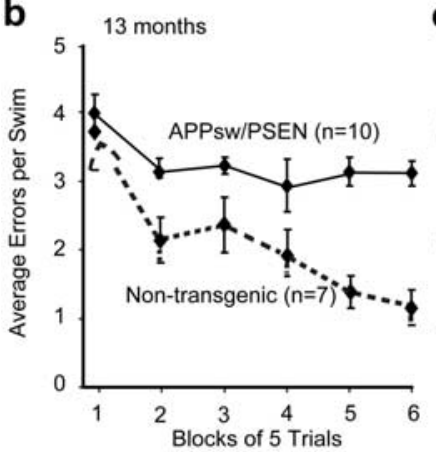

C 4 months

d

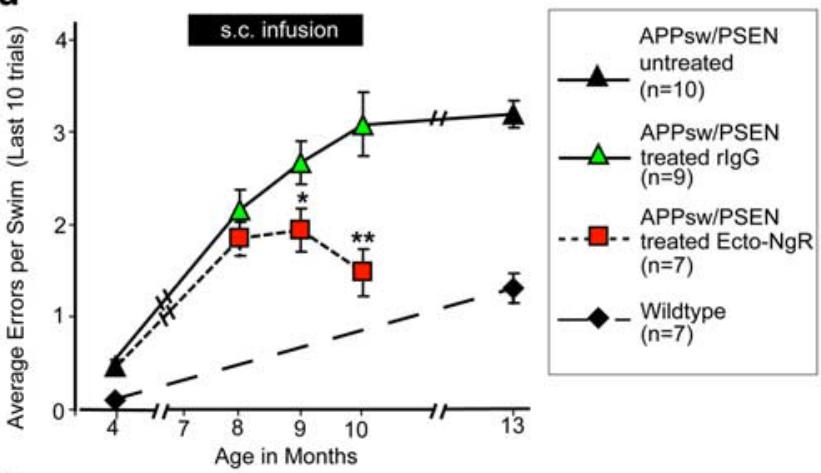

e

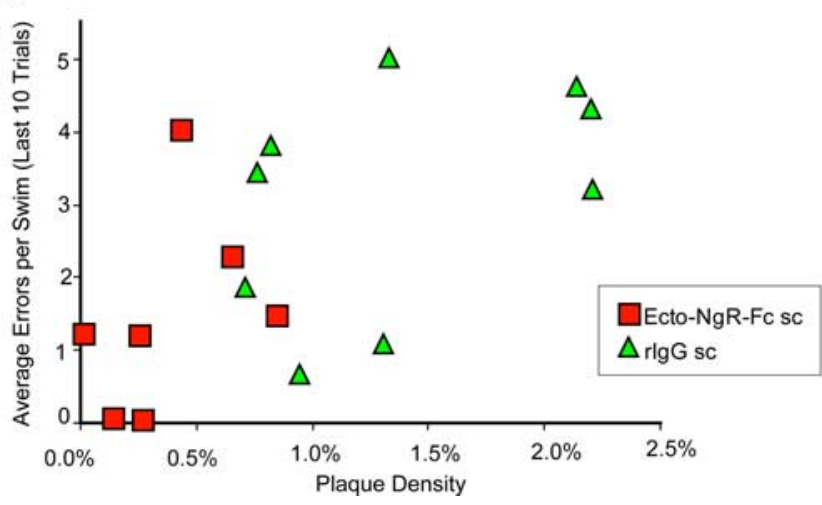

Figure 5. Subcutaneous treatment of $\mathrm{NgR}(310)$ ecto- $\mathrm{Fc}$ improves RAWM performance in APPswe/PSEN-1 $\Delta$ E9 transgenic mice. $\boldsymbol{a}$, Average number of errors for the indicated swim trials in a six-arm radial water maze for APPswe/PSEN-1 $\Delta$ E9 and wild-type littermates at 4 months of age. $\boldsymbol{b}$, Average number of errors in a six-arm radial water maze for APPswe/PSEN-1 $1 \Delta$ E9 and wild-type littermates at 13 months of age. $c$, Average number of errors in a six-arm radial water maze for $n g r^{+/-}$and $n g r^{-1-}$ mice. $\boldsymbol{d}$, Subcutaneous (s.c.) treatment of NgR(310)ecto- Fc improved performance in APPswe/PSEN-1 $\triangle$ E9 mice from months 7 to 10 and were tested at months $8-10$. The data for 4 and 13 months are from a separate cohort of mice that did not receive treatment. ${ }^{*} p<0.05$, significantly less than the lgG group at the same age (ANOVA); ${ }^{* *} p<0.02$ (ANOVA). $\boldsymbol{e}$, Scatter plot between plaque density and average errors per swim for the last 10 trials for each mouse. All data are mean \pm SEM for the indicated numbers of mice in each group. segment of a range of cell-surface receptors, including NgR, Trk receptors, Toll-like receptors, follicle-stimulating hormone/luteinizing hormone and related G-protein-coupled receptors, and platelet GP1b $\alpha$ (Kobe and Deisenhofer, 1994). Like the NgR, the platelet GP1b $\alpha$ interacts with unrelated protein ligands, von Willebrand's factor, and thrombin. Although A $\beta$, Nogo-66, MAG, and OMgp share no sequence similarity, they each bind to $\mathrm{NgR}$. For $\mathrm{A} \beta$ and Nogo-66, binding sites defined by mutagenesis appear closely apposed along the midportion of the concave surface. Structural studies of ligand/receptor will be required to further illuminate NgR binding and to explore the possibility of small molecule NgR ligand compounds as therapeutic agents. In summary, we show that subcutaneous $\mathrm{NgR}(310)$ ecto-Fc binds $\mathrm{A} \beta$ in the periphery to reduce $A \beta$ and improve spatial memory in a mouse model of AD.

\section{References}

Arancio O, Zhang HP, Chen X, Lin C, Trinchese F, Puzzo D, Liu S, Hegde A, Yan SF, Stern A, Luddy JS, Lue LF, Walker DG, Roher A, Buttini M, Mucke L, Li W, Schmidt AM, Kindy M, Hyslop PA, et al. (2004) RAGE potentiates Abeta-induced perturbation of neuronal function in transgenic mice. EMBO J 23:4096-4105.

Bard F, Cannon C, Barbour R, Burke RL, Games D, Grajeda H, Guido T, Hu K, Huang J, Johnson-Wood K, Khan K, Kholodenko D, Lee M, Lieberburg I, Motter R, Nguyen M, Soriano F, Vasquez N, Weiss K, Welch B, et al. (2000) Peripherally administered antibodies against amyloid betapeptide enter the central nervous system and reduce pathology in a mouse model of Alzheimer disease. Nat Med 6:916-919.

Bertram L, Blacker D, Mullin K, Keeney D, Jones J, Basu S, Yhu S, McInnis MG, Go RC, Vekrellis K, Selkoe DJ, Saunders AJ, Tanzi RE (2000) Evidence for genetic linkage of Alzheimer's disease to chromosome 10q. Science 290:2302-2303.

Birmingham K, Frantz S (2002) Set back to Alzheimer vaccine studies. Nat Med 8:199-200.

Deane R, Du Yan S, Submamaryan RK, LaRue B, Jovanovic S, Hogg E, Welch D, Manness L, Lin C, Yu J, Zhu H, Ghiso J, Frangione B, Stern A, Schmidt AM, Armstrong DL, Arnold B, Liliensiek B, Nawroth P, Hofman F, et al. (2003) RAGE mediates amyloid-beta peptide transport across the bloodbrain barrier and accumulation in brain. Nat Med 9:907-913 .

DeMattos RB, Bales KR, Cummins DJ, Dodart JC, Paul SM, Holtzman DM (2001) Peripheral anti-A beta antibody alters CNS and plasma A beta clearance and decreases brain A beta burden in a mouse model of Alzheimer's disease. Proc Natl Acad Sci USA 98:8850-8855.

Dodart JC, Bales KR, Gannon KS, Greene SJ, DeMattos RB, Mathis C, DeLong CA, Wu S, Wu X, Holtzman DM, Paul SM (2002) Immunization reverses memory deficits without reducing brain Abeta burden in Alzheimer's disease model. Nat Neurosci 5:452-457.

Fan QR, Hendrickson WA (2005) Structure of human follicle-stimulating hormone in complex with its receptor. Nature 433:269-277.

Fournier AE, GrandPre T, Strittmatter SM (2001) Identification of a receptor mediating Nogo-66 inhibition of axonal regeneration. Nature 409:341-346.

Fournier AE, Takizawa BT, Strittmatter SM (2003) Rho kinase inhibition enhances axonal regeneration in the injured CNS. J Neurosci 23:1416-1423.

Frautschy SA, Cole GM, Baird A (1992) Phagocytosis and deposition of vascular beta-amyloid in rat brains injected with Alzheimer beta-amyloid. Am J Pathol 140:1389-1399.

Glenner GG, Wong CW, Quaranta V, Eanes ED (1984) The amyloid deposits in Alzheimer's disease: their nature and pathogenesis. Appl Pathol 2:357-369.

GrandPre T, Li S, Strittmatter SM (2002) Nogo-66 receptor antagonist peptide promotes axonal regeneration. Nature 417:547-551.

Hardy J, Selkoe DJ (2002) The amyloid hypothesis of Alzheimer's disease: progress and problems on the road to therapeutics. Science 297:353-356.

Hu F, Liu BP, Budel S, Liao J, Chin J, Fournier A, Strittmatter SM (2005) Nogo-A interacts with the Nogo-66 receptor through multiple sites to create an isoform-selective subnanomolar agonist. J Neurosci 25:5298-5304.

Iwata N, Tsubuki S, Takaki Y, Shirotani K, Lu B, Gerard NP, Gerard C, Hama 
E, Lee HJ, Saido TC (2001) Metabolic regulation of brain Abeta by neprilysin. Science 292:1550-1552.

Kim JE, Liu BP, Park JH, Strittmatter SM (2004) Nogo-66 receptor prevents raphespinal and rubrospinal axon regeneration and limits functional recovery from spinal cord injury. Neuron 44:439-451.

Kobe B, Deisenhofer (1994) The leucine-rich repeat: a versatile binding motif. Trends Biochem Sci 19:415-421.

Lanz TA, Himes CS, Pallante G, Adams L, Yamazaki S, Amore B, Merchant KM (2003) The gamma-secretase inhibitor $\mathrm{N}-[\mathrm{N}-(3,5-$ difluorophenacetyl)-L-alanyl]-S-phenylglycine t-butyl ester reduces A beta levels in vivo in plasma and cerebrospinal fluid in young (plaquefree) and aged (plaque-bearing) Tg2576 mice. J Pharmacol Exp Ther 305:864-871.

Lee VM (2001) Abeta immunization: moving Abeta peptide from brain to blood. Proc Natl Acad Sci USA 98:8931-8932.

Levites Y, Das P, Price RW, Rochette MJ, Kostura LA, McGowan EM, Murphy MP, Golde TE (2006) Anti-Abeta42- and anti-Abeta40-specific mAbs attenuate amyloid deposition in an Alzheimer disease mouse model. J Clin Invest 116:193-201.

Li J, Ma J, Potter H (1995) Identification and expression analysis of a potential familial Alzheimer disease gene on chromosome 1 related to AD3. Proc Natl Acad Sci USA 92:12180-12184.

Li S, Strittmatter SM (2003) Delayed systemic Nogo-66 receptor antagonist promotes recovery from spinal cord injury. J Neurosci 23:4219-4227.

Li S, Liu BP, Budel S, Li M, Ji B, Walus L, Li W, Jirik A, Rabacchi S, Choi E, Worley D, Sah DW, Pepinsky B, Lee D, Relton J, Strittmatter SM (2004) Blockade of nogo-66, myelin-associated glycoprotein, and oligodendrocyte myelin glycoprotein by soluble nogo-66 receptor promotes axonal sprouting and recovery after spinal injury. J Neurosci 24:10511-10520.

Li S, Kim JE, Budel S, Hampton TG, Strittmatter SM (2005) Transgenic inhibition of Nogo-66 receptor function allows axonal sprouting and improved locomotion after spinal injury. Mol Cell Neurosci 29:26-39.

Liu BP, Fournier A, GrandPre T, Strittmatter SM (2002) Myelin-associated glycoprotein as a functional ligand for the Nogo-66 receptor. Science 297:1190-1193.

Matsuoka Y, Saito M, LaFrancois J, Saito M, Gaynor K, Olm V, Wang L, Casey E, Lu Y, Shiratori C, Lemere C, Duff K (2003) Novel therapeutic approach for the treatment of Alzheimer's disease by peripheral administration of agents with an affinity to $\beta$-amyloid. J Neurosci 23:29-33.

McGee AW, Strittmatter SM (2003) The Nogo-66 receptor: focusing myelin inhibition of axon regeneration. Trends Neurosci 26:193-198.

McGee AW, Yang Y, Fischer QS, Daw NW, Strittmatter SM (2005) Experience-driven plasticity of visual cortex limited by myelin and Nogo receptor. Science 309:2222-2226.

McLaurin J, Kierstead ME, Brown ME, Hawkes CA, Lambermon MH, Phinney AL, Darabie AA, Cousins JE, French JE, Lan MF, Chen F, Wong SS, Mount HT, Fraser PE, Westaway D, George-Hyslop PS (2006) Cyclohexanehexol inhibitors of Abeta aggregation prevent and reverse Alzheimer phenotype in a mouse model. Nat Med 12:801-808.

Morgan D, Diamond DM, Gottschall PE, Ugen KE, Dickey C, Hardy J, Duff K, Jantzen P, DiCarlo G, Wilcock D, Connor K, Hatcher J, Hope C,
Gordon M, Arendash GW (2000) Abeta peptide vaccination prevents memory loss in an animal model of Alzheimer's disease. Nature 408:982-985.

Orgogozo JM, Gilman S, Dartigues JF, Laurent B, Puel M, Kirby LC, Jouanny P, Dubois B, Eisner L, Flitman S, Michel BF, Boada M, Frank A, Hock C (2003) Subacute meningoencephalitis in a subset of patients with AD after Abeta42 immunization. Neurology 61:46-54.

Park JH, Gimbel DA, GrandPre T, Lee JK, Kim JE, Li W, Lee DH, Strittmatter SM (2006) Alzheimer precursor protein interaction with the Nogo-66 receptor reduces amyloid- $\beta$ plaque deposition. J Neurosci 26:1386-1395.

Qiu WQ, Walsh DM, Ye Z, Vekrellis K, Zhang J, Podlisny MB, Rosner MR, Safavi A, Hersh LB, Selkoe DJ (1998) Insulin-degrading enzyme regulates extracellular levels of amyloid beta-protein by degradation. J Biol Chem 273:32730-32738.

Schenk D (2002) Amyloid-beta immunotherapy for Alzheimer's disease: the end of the beginning. Nat Rev Neurosci 3:824-828.

Schenk D, Barbour R, Dunn W, Gordon G, Grajeda H, Guido T, Hu K, Huang J, Johnson-Wood K, Khan K, Kholodenko D, Lee M, Liao Z, Lieberburg I, Motter R, Mutter L, Soriano F, Shopp G, Vasquez N, Vandevert C, et al. (1999) Immunization with amyloid-beta attenuates Alzheimer-diseaselike pathology in the PDAPP mouse. Nature 400:173-177.

Sinha S, Anderson JP, Barbour R, Basi GS, Caccavello R, Davis D, Doan M, Dovey HF, Frigon N, Hong J, Jacobson-Croak K, Jewett N, Keim P, Knops J, Lieberburg I, Power M, Tan H, Tatsuno G, Tung J, Schenk D, et al. (1999) Purification and cloning of amyloid precursor protein betasecretase from human brain. Nature 402:537-540.

Vassar R, Bennett BD, Babu-Khan S, Kahn S, Mendiaz EA, Denis P, Teplow DB, Ross S, Amarante P, Loeloff R, Luo Y, Fisher S, Fuller J, Edenson S, Lile J, Jarosinski MA, Biere AL, Curran E, Burgess T, Louis JC, et al. (1999) Beta-secretase cleavage of Alzheimer's amyloid precursor protein by the transmembrane aspartic protease BACE. Science 286:735-741.

Wang KC, Koprivica V, Kim JA, Sivasankaran R, Guo Y, Neve RL, He Z (2002) Oligodendrocyte-myelin glycoprotein is a Nogo receptor ligand that inhibits neurite outgrowth. Nature 417:941-944.

Weiner HL, Selkoe DJ (2002) Inflammation and therapeutic vaccination in CNS diseases. Nature 420:879-884.

Wilcock DM, Alamed J, Goltschall PE, Grimm J, Rosenthal A, Pons J, Ronan V, Symmonds K, Gordon MN, Morgan D (2006) Deglycosylated antiamyloid- $\beta$ antibodies eliminate cognitive deficits and reduce parenchymal amyloid with minimal vascular consequences in aged amyloid precursor protein transgenic mice. J Neurosci 26:5340-5346.

Yaar M, Zhai S, Pilch PF, Doyle SM, Eisenhauer PB, Fine RE, Gilchrest BA (1997) Binding of beta-amyloid to the p75 neurotrophin receptor induces apoptosis. A possible mechanism for Alzheimer's disease. J Clin Invest 100:2333-2340.

Yasojima K, Akiyama H, McGeer EG, McGeer PL (2001) Reduced neprilysin in high plaque areas of Alzheimer brain: a possible relationship to deficient degradation of beta-amyloid peptide. Neurosci Lett 297:97-100.

Younkin SG (2001) Amyloid beta vaccination: reduced plaques and improved cognition. Nat Med 7:18-19. 